Irena V. Vodopija-Krstanović

Sveučilište u Rijeci

Filozofski fakultet, Odsjek za anglistiku

ivodopija@ffri.hr

\section{Dorina R. Badurina}

Srednja škola Andrije Ljudevita Adamića, Rijeka

dorina.badurina@ss-adamic.com

\title{
INTEGRIRANO USVAJANJE STRANOGA JEZIKA I SADRŽAJA (CLIL): PREDNOSTI, IZAZOVI I MJERE
}

\begin{abstract}
APSTRAKT: Integrirano poučavanje jezika i sadržaja (eng. CLIL) inovativni je pristup nastavi koji potiče višejezično obrazovanje u Europi. Iznimno je važno da $C L I L$ nastavnici imaju jezične i metodičke kompetencije za poučavanje sadržaja (nastavnih predmeta) na stranome jeziku, izradu materijala, provjeravanje znanja i upravljanje učionicom. Međutim, mali broj nastavnika posjeduje navedene kompetencije. Uporabom polustrukturiranih intervjua s osam nastavnika uključenih u CLIL nastavu u jednoj riječkoj gimnaziji u ovome se radu ispituju njihovi stavovi prema $C L I L$-u, izazovi s kojima se susreću i mjere koje bi preporučili za savladavanje izazova CLIL-a. Rezultati upućuju da nastavnici imaju pozitivan stav prema $C L I L$-u i podržavaju njegovo uvođenje. Poteškoće s kojima se susreću odnose se na nedostatno poznavanje stranoga jezika, prilagodbu nastavnih materijala nastavi na stranome jeziku, poravnavanje CLIL predmeta $\mathrm{s}$ kurikulom i provjerom učenikova znanja. Zaključujemo da valja više pozornosti posvetiti tom obliku nastave u školama.
\end{abstract}

Ključne riječi: CLIL, nastavnici, stavovi, izazovi, mjere, strani jezici, nastava.

\section{CONTENT AND LANGUAGE INTEGRATED LEARNING (CLIL): BENEFITS, CHALLENGES AND MEASURES}

ABSTRACT: Content and language integrated learning (CLIL) is considered to be an innovative approach to fostering multilingual education in Europe. In order to teach effectively, CLIL teachers should have linguistic and methodological competences for subject teaching, assessment, materials development and classroom management in a foreign language. However, not many subject teachers have the necessary language and pedagogical skills. Drawing on data obtained through semi-structured interviews with CLIL teachers, we examine their attutudes towards CLIL, the challenges of teaching CLIL, and the measures to address these challenges. The findings show that teachers have positive attitudes towards CLIL. The problems they face are related to: a) inadequate language proficiency, b) dual-focused form of instruction, c) adaptation and design of course 
material, d) alignment of CLIL subjects with national guidelines, and e) assessment. It will be argued that CLIL warrants greater attention and support.

Key words: CLIL, teachers, attitudes, challenges, measures, foreign languages, teaching.

\section{UVOD}

Posljednjih je dvadesetak godina $u$ europskim školama vidljiv porast integriranog učenja sadržaja i jezika (eng. Content and language integrated learning, u daljnjem tekstu CLIL). Termin CLIL uveden je sredinom devedesetih godina prošloga stoljeća u Europi, gdje se ponajprije rabi za pristup u kojem strani jezik služi kao sredstvo za učenje i poučavanje nejezičnih predmeta u školi (Nikula 2017), a pritom se pažnja ne usmjerava samo na jezik, već i na sadržaj (Coyle et al. 2010). Stoga se CLIL smatra „europskim pristupom bilingvalnom obrazovanju” (Nikula 2017: 111). Iako se CLIL i danas smatra inovativnom metodom, petnaest godina prije razvoja CLIL-a u Europi, osamdesetih godina prošloga stoljeća, u Sjedinjenim Američkim Državama započela je integrirana nastava sadržaja i jezika (eng. content-based instruction - CBI), namijenjena učenicima kojima je engleski drugi jezik. S gledišta jezičnih i obrazovnih ciljeva nema značajnih razlika između $C L I L$-a i $C B I$-a (Cenoz 2015).

Dva su ključna dokumenta postavila temelje za uvođenje višejezičnog obrazovanja u Europi: Rezolucija o unaprjeđenju i diversifikaciji učenja i poučavanja jezika unutar obrazovnih sustava Europske unije (Council Resolution on improving and diversifying language learning and teaching within the education systems of the European Union) iz 1995. godine i Bijela knjiga o obrazovanju (White Paper on Education and Training: Teaching and Learning - Towards the Learning Society), također iz 1995. godine. Rezolucija promovira uporabu inovativnih metoda $u$ nastavi $i$ ističe važnost poučavanja predmeta nejezičnih disciplina na stranom jeziku, dok Bijela knjiga navodi da bi učenici srednjih škola trebali slušati neke predmete na prvom stranom jeziku. Također valja istaknuti da su Vijeće Europe i Europski centar za moderne jezike podržavali i poticali CLIL od samih početaka, a kao podršku CLIL nastavnicima izradili su Europski okvir za obrazovanje CLIL nastavnika (Marsh, Mehisto, Wolff, Frigols Martin 2010; Geiger-Jaillet, Wolff, Mehisto, Marsh 2011).

Budući da je CLIL pristup poučavanju i učenju predmeta u kojem je strani jezik zamijenio materinski, bilo je potrebno izraditi metodički pristup poučavanju. Temeljne postavke za poučavanje dao je Coyle (1999) sa svojim „4C” okvirom, koji obuhvaća četiri područja: sadržaj, komunikaciju, kogniciju i kulturu (eng. content, communication, cognition i culture). Prema tom modelu jezik je i cilj i 
sredstvo poučavanja na nastavi, ali valja napomenuti da integrirano poučavanje jezika i sadržaja ne podrazumijeva jednaku usmjerenost na jezik i sadržaj (Stoller i Fitzsimmons-Doolan 2017). S obzirom na to u kojoj se mjeri ostvaruju jezični ciljevi, CLIL možemo podijeliti u dvije kategorije: slabi CLIL (eng. weak CLIL) ili jaki CLIL (eng. strong CLIL). Slaba inačica $C L I L$-a je ponajprije usmjerena na učenje jezika, dok je snažna inačica usmjerena na učenje sadržaja, a strani je jezik u službi predmeta (Ball, Kelly i Clegg 2015). Prema Eurydice (2006), u CLIL-u se predmet ne poučava na stranome jeziku nego sa stranim jezikom jer su oboje usko povezani. Međutim, tu se otvara pitanje ostvarivanja jezičnih ishoda u CLIL-u, te u kojoj je mjeri CLIL funkcionalna metoda za poučavanje i učenje stranih jezika (Dalton-Puffer 2011).

Razvidno je da CLIL ima veliki značaj u europskome kontekstu jer je višejezičnost u središtu europskoga identiteta, što je važan aspekt europskog obrazovanja (Council recommendation of 22 May 2019 on a comprehensive approach to the teaching and learning of languages). Komunikacija na stranome jeziku jedna je od ključnih osam kompetencija za cjeloživotno učenje (Council recommendation of 22 May 2018 on on Key Competences for LifeLong Learning). S obzirom na to da je od samih početaka CLIL uživao veliku podršku, iznimno se brzo širio Europom, a prema Euridyceovom izvješću o CLIL-u iz 2006. godine mali broj zemalja nije provodilo CLIL, među njima i Hrvatska (Euridyce 2006). Jedanaest godina kasnije CLIL se provodi u skoro svim europskim zemljama (Eurydice 2017), no istovremeno u Hrvatskoj se samo $1,1 \%$ djece obrazuje na jeziku koji ne govore u kući, što implicitno ukazuje da CLIL i nije rasprostranjen.

S obzirom na vrstu $C L I L$-a, u školama u Hrvatskoj dominira jaka inačica budući da se ciljevi i ishodi učenja određuju prema kurikulu predmeta. Stoga je jezik podređen sadržaju. Razlog tome jest i činjenica da CLIL nastavnici nemaju nužno filološko obrazovanje, jezične kompetencije i metalingvističko znanje da bi se mogli baviti jezikom i ostvarivati jezične ishode. Valja također uzeti u obzir da državna matura nije prilagođena CLIL nastavi.

\section{PREDNOSTI I IZAZOVI CLIL-A}

Temeljna prednost $C L I L$-a jest da učenicima pruža više prilika koristiti strani jezik nego na nastavi stranoga jezika (Chen i Kraklow 2014; Nikula 2005) i jezik se nenamjerno uči na učinkovit način u prirodnim komunikacijskim situacijama (Lasagabaster 2008). Stoga učenici u CLIL-u imaju višu razinu stranoga jezika od učenika koji ga uče isključivo na nastavi stranoga jezika (Lasagabaster i Doiz 2016), a pritom nemaju slabije znanje predmeta od učenika 
koji ga slušaju na materinskome jeziku (Badertscher i Bieri 2009, Heine 2008). U CLIL-u učenikov se vokabular obogaćuje uporabom stručne terminologije, a gramatika je kontekstualizirana i uči se u autentičnim situacijama. CLIL također potiče internacionalnu dimenziju škole, olakšava mobilnost učenika i nastavnika, te sudjelovanje u međunarodnim projektima. CLIL nastava je fleksibilna i može se prilagoditi potrebama obrazovne ustanove i učenika (Nikula 2017).

Međutim, jedan od temeljnih nedostataka jest da u stvarnosti, CLIL nije usklađen s europskom višejezičnom politikom, jer se nastava najčešće ostvaruje na engleskome jeziku (Nikula 2017). Stoga ne čudi da Graddol CLIL definira kao „bilingvalni pristup obrazovanju u kojem se zajedno poučavaju sadržaj kurikula, kao primjerice prirodoslovni predmeti ili zemljopis, i engleski jezik" (2006: 86). Neosporno je da engleski jezik čini CLIL nastavu privlačnijom, jer u suvremenome svijetu, engleski je lingua franca i najrasprostranjeniji međunarodni jezik (eng. English as an international language) koji omogućuje globalnu komunikaciju među neizvornim govornicima, te ga tako valja koncipirati i poučavati (Jenkins 2007; McKay 2018; Vodopija-Krstanović i Brala Vukanović 2012; VodopijaKrstanović i Marinac 2019). Dodatni razlog zašto se CLIL ponajprije odvija na engleskome jest što se smatra da engleski jezik bolje priprema učenike za internacionalizaciju i iznimno popularnu visokoškolsku nastavu na engleskome jeziku (eng. English-medium instruction), tj. za studiranje na engleskome jeziku (Drljača-Margić i Vodopija-Krstanović 2017). Što se tiče učenja stranoga jezika u $C L I L$-u, on je često u funkciji struke, pa se ne pridaje dostatna pozornost jezičnoj sastavnici (Lyster i Mori 2007). Učenje stranog jezika usmjereno je na razvijanje (stručnog) vokabulara, a nedovoljno se razvija jezična komunikacijska kompetencija i gramatička točnost (cf. Basturkmen 2018). CLIL nastavnici u pravilu se ne osvrću na gramatiku stranoga jezika (Lasagabaster i Doiz 2016). Diskurs je manje složen nego na nastavi na materinskome jeziku, nastavnici uglavnom postavljaju zatvorena pitanja, a učenici daju kratke jednostavne odgovore i koriste jednostavne rečenice (Dalton-Puffer 2007). Iznimno je teško odrediti jezične ishode učenja u CLIL predmetu (cf. Brevik i Moe 2012; DaltonPuffer 2008). Nedostatno razvijene nastavnikove jezične kompetencije također predstavljaju prepreku (cf. Vilkancienè i Rozgienè 2017), što se odražava i na kvalitetu nastave (Marsh, Hau i Kong 2002). Socioekonomski gledano, CLIL se izvodi u gradovima, pa nemaju svi učenici jednake mogućnosti pohađanja CLIL nastave, a često se provodi i u privatnim školama, pa je djeci nižeg socioekonomskog statusa CLIL manje dostupan. Nastavnici u $C L I L$-u najčešće nisu metodički osposobljeni, niti su jednako kompetentni za poučavanje sadržaja i stranog jezika (Lo 2014), a otežavajuća je okolnost što je iznimno teško odrediti i 
ostvariti jezične ishode u CLIL predmetu. Inicijalno obrazovanje ne osposobljava nastavnike za CLIL i tek iskustvo stečeno u CLIL-u omogućuje razvijanje potrebnih nastavničkih kompetencija (Ball, Kelly i Clegg 2015; Housen 2013). Složenost pripreme za CLIL nastavu zahtijeva više vremena (cf. Tsuneyoshi 2005), usto nastavnici nisu adekvatno nagrađeni (McDougald 2015). Naposljetku, na tržištu je nedostatak nastavnika koji su kompetentni da odgovore izazovima CLIL-a (Mehisto, Marsh i Frigols 2008).

\section{METODOLOGIJA ISTRAŽIVANJA}

U ovome se dijelu opisuju ciljevi istraživanja, istraživačka pitanja, metoda, ispitanici, te kontekst u kojemu je istraživanje provedeno.

\subsection{Cilj rada i istraživačka pitanja}

Cilj je rada istražiti stavove nastavnika prema CLIL-u, izazove s kojima se nastavnici susreću kada poučavaju predmet na stranome jeziku, te mjere koje bi nastavnici predložili za poboljšanje kvalitete nastave i olakšavanje procesa poučavanja.

Istraživanje se temelji na trima istraživačkim pitanjima:

IP 1: Kakav je stav nastavnika prema CLIL-u?

IP 2: S kojim se izazovima i preprekama nastavnici susreću tijekom provedbe $C L I L-\mathrm{a}$ ?

IP 3: Kakvo je mišljenje nastavnika o mjerama za poboljšanje $C L I L-a$ ?

\subsection{Ispitanici i kontekst}

Istraživanje je provedeno u gimnazijskim razrednim odjelima privatne Srednje škole Andrije Ljudevita Adamića u Rijeci, Republici Hrvatskoj. Škola je osnovana 2005. godine i ima četiri razreda opće gimnazije. Od 2015. godine CLIL nastava održava se na engleskom, njemačkom i talijanskom jeziku u sklopu redovne nastave. Nastava CLIL-a uvela se u školi putem europskog projekta „Višejezično obrazovanje - unaprjeđenje učenja jezika i interkulturalnih vještina” u sklopu IV. komponente IPA programa, sheme za dodjelu bespovratnih sredstava „Daljnji razvoj i provedba Hrvatskog kvalifikacijskog okvira”. Članovi Odsjeka za anglistiku Filozofskoga fakulteta Sveučilišta u Rijeci sudjelovali su u projektu kao evaluatori i konzultanti. Glavni je bio cilj projekta osigurati preduvjete za sustavno uvođenje CLIL-a. Unutar projekta provele su se sljedeće aktivnosti: stručno usavršavanje nastavnika u području jezika, uvođenje i uporaba CLIL metodologije 
u poučavanje sadržaja školskog kurikuluma na stranome jeziku, definiranje ishoda učenja u skladu s pripadajućim HKO standardima, studijska putovanja u inozemstvo u gimnazije koje provode CLIL, razvoj modula za poučavanje nastavnih predmeta na stranome jeziku, izrada i pilotiranje nastavnih materijala, okrugli stolovi i akcijsko istraživanje.

U ovome je istraživanju sudjelovalo osam CLIL nastavnika koji poučavaju nejezične predmete na stranome jeziku. Nastavnici tijekom inicijalnog obrazovanja nisu imali obuku za CLIL, niti su završili dvopredmetni jezični program nastavničkoga smjera. Kada su počeli primjenjivati CLIL metodu, svi su nastavnici završili tečaj stranoga jezika u školi stranih jezika u Rijeci i provjeru znanja stranoga jezika. Nastavnici su sudjelovali i u radionicama o CLIL metodologiji, te posjetili škole u inozemstvu u kojima se CLIL provodi. Raspon njihove razine stranoga jezika jest od B2 do C1 prema Zajedničkom europskom referentnom okviru, a dobni je raspon nastavnika od 28 do 45 godina starosti.

\subsection{Istraživačka metoda}

Ova studija slučaja temelji se na interpretativističkoj paradigmi i kvalitativnome istraživanju (vidi Denzin i Lincoln 1998). Razlog odabira paradigme jest što omogućuje razumijevanje određenog fenomena s gledišta onih koji su to iskustvo proživjeli. Stoga se u ovom istraživanju nastojalo razumjeti i interpretirati individualne odgovore sudionika istraživanja da bi se dobio dubinski uvid u perspektive grupe nastavnika u CLIL-u. Kao metoda za prikupljanje podataka rabio se polustrukturirani intervju na svrsishodnom uzorku. Prilikom vođenja intervjua poticalo se sudionike da izraze svoje mišljenje i otvore teme koje su im relevantne. Intervju je trajao od 40 do 60 minuta i vođen je na hrvatskome jeziku. Svi su intervjui snimljeni i transkribirani. Transkripcija je iščitana nekoliko puta, nakon čega se pristupilo analizi i kodiranju intervjua prema temama koje su identificirane tijekom čitanja (vidi Gibbs 2007). Usporedbom odgovora i uočavanjem sličnosti interpretirali su se rezultati izneseni u ovome radu (cf. Gibbs 2007). Rezultati su prikazani prema sljedećim identificiranim temama: stavovi prema $C L I L-u$, jezična kompetencija, nastavni materijali na stranome jeziku, poravnavanje $C L I L$ predmeta s nacionalnim kurikulom, provjera znanja i prijedlozi za poboljšanje postojeće prakse. 


\section{REZULTATI I RASPRAVA}

\subsection{Stavovi prema CLIL-u}

Analiza podataka pokazuje da nastavnici imaju pozitivne stavove prema CLIL metodi, jer im omogućuje profesionalni razvoj, cjeloživotno učenje, te bolju suradnju s drugim nastavnicima.

Dobio sam 3 certifikata! (N 5)

Neprestano učim, jako je važno da usavršavam svoj engleski. (N 6)

Sudjelovao sam u programu usavršavanja u Velikoj Britaniji $i$ svi smo prošli radionice o CLIL metodologiji... (N 2)

Sudjelovanjem u programima stručnog usavršavanja nastavnici su stekli kompetencije potrebne za nove uloge i dobili su vjeru u sebe i vlastite mogućnosti za obavljanje posla i postizanje ciljeva.

Za sada osjećam se kompetentna. Svjesna sam da baš ne radim skroz po principima CLIL-a, ali kada sam vidjela kako se radi u Španjolskoj $i$ njihov tempo rada, shvatila sam da to što radim je dosta dobro i da sam samo pre samokritična. (N 6)

CLIL nastavnici navode da više surađuju s predmetnim nastavnicima pri pisanju kurikula i pripremanju nastavnih materijala. Trude se češće surađivati i s nastavnikom stranoga jezika, posebice pri kreiranju testova i ispravljanju učenikovih radova, iako je to teško s obzirom na opterećenje nastavnika stranih jezika (cf. Vázquez i Méndez García 2017).

Surađujem sa svojim kolegama iz CLIL-a, dijelimo zadatke, testove, materijale... Dobar smo tim. (N 4)

Surađujemo, opažali smo međusobno satove, raspravljamo kako strukturirati sat. (N 2)

Surađujem s nastavnicom engleskoga jezika kada pripremam materijale, a imamo sastanke CLIL nastavnika i razmjenjujemo iskustva. (N 1)

Prije sata pokažem svoju pripremu nastavnici engleskoga i ona mi ispravi greške i razgovaramo o stručnoj terminologiji. (N 8)

Zajedno smo pisali program, nastavnica engleskog mi je pomogla napisati ishode i po potrebi ih je ispravila. (N 1) 
Nadalje, nastavnici smatraju da CLIL učenicima pruža više prilika za uporabu stranoga jezika u prirodnim komunikacijskim situacijama (cf. Lasagabaster 2008), a učenici su manje opterećeni gramatičkom točnošću iskaza, jer su nastavnici usmjereni na sadržaj, a ne na jezične strukture. Nastavnici ističu da učenici u $C L I L$-u postižu bolje rezultate na testovima stranoga jezika i tečnije govore strani jezik (Lasagabaster 2008), a pritom nemaju slabije znanje predmeta. Ističu da je CLIL odličan alat za stjecanje jezičnih kompetencija, te da CLIL metoda može biti učinkovitija od nastave stranog jezika.

Učenje jezika odvija se slučajno, ne radimo intencijalno na gramatičkim strukturama, učenje jezika se samo događa usput, ovisi o sadržaju kojeg učimo. (N 6)

Mislim da im je lakše govoriti engleski u CLIL predmetu nego na satu engleskog, jer nisu pod povećalom. (N 1)

Nije dovoljno danas učiti jezik samo tri sata na tjedan. Ne može se tako postići dobra razina znanja jezika. (N 6)

Usprkos pozitivnim stavovima prema $C L I L$-u, nastavnici ne kriju poteškoće koje CLIL pred njih postavlja.

\subsection{Jezična kompetencija i dualni fokus}

Temeljni je izazov nastavnikovo nedostatno znanje jezičnih zakonitosti unatoč završenim jezičnim tečajevima i položenim ispitima za B2 i C1 razine. Nastavnici navode da nailaze na jezične poteškoće, te osjećaju potrebu za nastavkom razvijanja jezičnih vještina. Iako imaju manje poteškoća s jezikom nego što su imali inicijalno, ipak su još uvijek nesigurni $u$ vlastitu sposobnost poučavanja na stranome jeziku (cf. Vázquez i Ellison 2013).

Meni sve predstavlja izazov, još uvijek nisam dovoljno sigurna u svoj engleski da poučavam sadržaj jezikom na svojoj razini. (N 2)

Nastavnici priznaju da se nedostatno razvijene jezične kompetencije mogu odraziti na učestalu uporabu materinskog jezika na nastavi, na kvalitetu same nastave i na nastavnikovo samopouzdanje (cf. Vilkancienè i Rozgienė 2017).

Nastavnici se ponekad srame govoriti stranim jezikom, učenici nisu problem, oni dobro govore engleski. Nastavnici imaju problem u sebi. (N 6) 
Stoga materinski jezik često rabe ako poučavaju složenu temu.

Neke teme namjerno radim na hrvatskom, jer je terminologija preteška, kad na primjer radimo mozak, nastava je na hrvatskom. (N 2)

Ako nastavnici rabe materinski jezik, i učenici će se njime služiti, odnosno neće pokušati prenijeti poruku na stranome jeziku.

Nastavnici se prebacuju na hrvatski prema svojim potrebama, a ne u skladu s potrebama djece. Učenici govore hrvatski koliko im to nastavnik dopusti. (N 8)

Zanimljivo je i da nastavnici ponekad rabe materinski jezik za davanje uputa i održavanje discipline na satu:

Rečem na hrvatskom kada će biti test ili kada moram nešto važno objasniti $u$ detalje. (N 8)

Kada su nemirni upozoravam ih na hrvatskom. Nisam sigurna bi li me ozbiljno shvatili da to radim na engleskom. (N 2)

Materinski im je jezik prirodniji i njime se brže i lakše mogu izraziti.

Kada krenemo u žučne rasprave, teško je držati se stranog jezika. (N 4)

Ponekad učenici kažu sram me je, mogu li to reći na hrvatskom, ali onda im drugi učenici kažu: Daj, probaj! Međusobno se bodre! (N 3)

Svi su se nastavnici složili da su usmjereni na sadržaj i svjesni su da bi više pažnje trebali posvećivati stranome jeziku, ali ne žele opteretiti učenike.

Stvar je u tome da ih ne smiješ frustrirati ili dati im još jedan predmet koji će im testirati znanje jezika, jer u CLIL-u nije cilj da ih stresiraš nego treba postići da se osjećaju slobodno i ohrabriti ih u izražavanju. (N 4)

Pripreme za nastavni sat trebaju sadržavati i jezične ishode iako se nastavnici često ne usmjeravaju na jezik.

Svaki sat ima svoje jezične ishode iako se mi ne usmjeravamo na njih, ali mora imati barem jedan ishod... (N 2) 
S druge strane, nastavnici stranoga jezika koji poučavaju sadržaj nisu za to osposobljeni i teško im je poučavati struku. Dvije nastavnice stranoga jezika koje poučavaju predmet Glazbene kulture izrazile su potrebu produbljenja znanja predmeta, jer im je katkada teško objašnjavati sadržaj s kojim nisu dobro upoznate, iako dobro vladaju jezikom.

Katkada previše gnjavim profesora glazbenog... Pitam ga da mi objasni što je to dodekafonska ljestvica, da mi objasni, da ja mogu objasniti djeci... (N 7) Teško je prenijeti novi sadržaj učenicima. Prvo moram nešto sebi objasniti da bi to isto mogao objasniti njima. (N 3 )

Temeljni je izazov CLIL-a što su nastavnici najčešće ili osposobljeni za poučavanje sadržaja ili stranog jezika, ali rijetko su jednako kompetentni za oboje, što otežava provedbu CLIL-a (Lo 2014). Stoga bi trebalo napraviti analizu potrebe nastavnika za poučavanje u CLIL-u i razviti tečajeve koji bi im pomogli unaprijediti vještine koje su potrebne za poučavanje na stranome jeziku (cf. Kampmark 2019).

\subsection{Nastavni materijali}

CLIL materijali za određeni predmet i nastavnu jedinicu ne postoje, posebice ne za hrvatske kurikule. Stoga odabir i kreiranje materijala predstavlja jedan od najvećih izazova u $C L I L$-u, a nastavnici provode sate na internetu tražeći adekvatne materijale.

Najveći je problem materijal, pronaći i pripremiti materijal. Moram sve pripremiti na engleskom, sve testove, previše vremena mi oduzima. (N 7)

Kad krenem surfati internetom, izgubim se. Onda shvatim da sam dva sata tražila i još uvijek nemam ništa. (N 4)

Izazov je što sve moram sama istražiti, pronaći... (N 5)

Kao što navodi i McDougald (2015), svi su nastavnici spomenuli da im je potrebno više vremena za pripremu nastavnog sata, jer neminovno pripremaju vlastite materijale i prilagođavaju hrvatske udžbenike.

Sve izmišljamo sami. Tražim na netu, imam hrvatski udžbenik, ali moram prilagođavati cijelo vrijeme. (N 1) 
Ne pišem detaljne jezične ishode za svaki sat jer nemam vremena, dovoljno vremena potrošim na materijalima za nastavu. (N 2)

Prilikom odabira materijala nastavnici navode da $\mathrm{u}$ obzir uzimaju prosječnu jezičnu razinu razreda. Autentične tekstove rijetko kada mogu preuzimati, stoga učenici većinom uče iz skripti koje im sami nastavnici pripremaju na stranome jeziku. Materijali koji su dostupni na stranom jeziku često su namijenjeni izvornim govornicima i nisu prilagođeni za CLIL nastavu.

Našla sam materijale na njemačkom, ali to je bilo za učenike koji su Nijemci, ne mogu to uzeti jer je jezik težak, uzmem to samo kao ideju. Nemoguće je naći materijal i samo ga preuzeti. (N 6)

\subsection{Poravnavanje CLIL predmeta s kurikulom}

Nastavnici objašnjavaju kako državna matura uvelike otežava implementaciju CLIL-a, jer postoji odstupanje CLIL kurikuluma od nacionalnog okvirnog kurikuluma. Sadržaj predmeta u CLIL-u manjeg je opsega, a terminologija koja se uči na stranom jeziku također je prepreka učenicima. Velika je odgovornost CLIL nastavnika koji treba osposobiti učenike za polaganje određenog predmeta državne mature na materinskom jeziku.

Problem je što imamo maturu, pa ako izaberu moj predmet na maturi, moram uzeti u obzir da moraju znati i sve termine na hrvatskom. (N 5)

Roditelji su se brinuli kako će CLIL utjecat na ocjene na maturi, hoće li učenici moći savladati sadržaj na stranome jeziku... što će se desiti na maturi? (N 1)

CLIL metodologija zahtijeva više vremena za provedbu, stoga sadržaj smije biti reduciran. Usprkos tome, nastavnici tvrde da je sadržaj koji trebaju obraditi na stranome jeziku preopsežan. Moraju slijediti kurikul i istovremeno odlučiti koji će sadržaj izbaciti ili pojednostaviti, što dovodi do neusklađenosti između nacionalnih ispita usmjerenih na sadržaj i CLIL-a, koji teži redukciji sadržaja (cf. Serragiotto 2007). S obzirom da nema smjernica Ministarstva znanosti i obrazovanja (MZO), nastavnici nisu sigurni postupaju li ispravno.

Mi radimo po kurikulu, ali smo u teškoj poziciji jer ne smijemo izbacivati neke sadržaje, ali u CLIL-u je nemoguće ne smanjiti sadržaj. (N 2) 
Teško je objasniti nastavnicima da reduciraju sadržaj, ne žele ništa izbaciti da ne oštete učenike. (N 7)

Prilagođavanje CLIL kurikula dodatno otežava činjenica da ne postoje nacionalne smjernice za provedbu CLIL metodologije, a nastavnicima nije osigurano dostatno vrijeme za provedbu. Pisanje CLIL kurikula i prilagođavanje u skladu s nacionalnim kurikulom iziskuje puno vremena i suradnje svih nastavnika u školi.

Jako je naporno usklađivanje sa službenim zahtjevima MZO, kreiranje promjena i modernizacija. (N 8)

U nezavidnom smo položaju jer se moramo držati smjernica Ministarstva $i$ propisanog programa, ali u CLIL-u ne možemo to sve pratiti i nemoguće je da barem nešto ne reduciramo. ( $\mathrm{N} 2)$

Nema nadzora u CLIL-u. Ne postoji osoba koja će ti reći treba nešto napraviti ovako ili ovo krivo radiš. (N 8)

\subsection{Provjera i procjena znanja}

Provjera znanja iznimno je važna tema u CLIL metodologiji. S obzirom na dualni pristup, važno je odrediti što, kada i kako se provjerava (Coyle, Hood i Marsh 2010). Već smo i spomenuli da je CLIL više usmjeren na sadržaj nego na jezik, što potvrđuju i svi školski nastavnici:

Svi se više usmjeravamo na sadržaj. Ocjenjujem samo sadržaj, možda nije tako dobro, ali ne zanemarujem jezik. (N 6)

Nastavnici objašnjavaju da prilikom vrednovanja znanja predmetni nastavnici samostalno odlučuju o ocjenjivanju. Iako je korektivna povratna informacija nastavnika važna (Bićanić i Opašić 2019), većina nastavnika ocjenjuje samo sadržaj, i samo ponekad daju i povratnu informaciju na jezik.

Katkad imam jezične kriterije, katkad ocjenjujem samo sadržaj. Ocjenjujem i jezik, ali ovisi o temi, učeniku, neki učenici ne razumiju, pa im moraš objasniti na hrvatskom ili ukratko pojasniti i pojednostaviti na engleskom. (N 5)

Iako CLIL ne podrazumijeva jednaku pažnju i usmjerenost na jezik i sadržaj (Stoller i Fitzsimmons-Doolan 2017), jezik se ne bi trebao zanemariti. 
Učenici pišu testove na stranom jeziku, ali nastavnici tvrde da jezik rijetko utječe na ocjenu, jer nemaju jasnih smjernica za procjenjivanje znanja.

Što se ocjenjuje? Nikad nismo dobili službeni odgovor na to pitanje, iako je bilo puno pitanja o tome, ali nema pravila. (N 2)

Razlog zbog kojega predmetni nastavnici znaju zanemariti jezik je taj što nemaju metalingvističkog znanja i ne poznaju diskurs predmeta, stoga nisu sigurni kako i što treba ocjenjivati.

Samo sadržaj ocjenjujem u testovima, većinom sadržaj, ako je baš jako jezik loš onda utječe na ocjenu (...) Ispravim greške, ali ne utječu na ocjenu. (N 1)

Nikada ne ocjenjujem jezik, nikada... Mislim da ne bi trebao biti važan nastavniku, a možda zato što nisam jezičar... imam osjećaj da ih ne bi trebala ocjenjivati, bez obzira na moj nivo engleskog. (N 4)

Istraživanja potvrđuju da CLIL pomaže učenicima da usvoje jezik (Hendrikx i Van Goethem 2020) i da ga nauče rabiti, a nastavnici bi pridavali više pažnje jeziku kada bi imali metalingvističko znanje (cf. Lo 2020).

Uče jezik kroz konverzaciju, na prirodan način, a nisu niti svjesni da ga uče. (N 5)

Učenici imaju bolji vokabular i provjerili smo im ocjene iz engleskog, poboljšale su im se. (N 6)

Neki učenici koji nisu bili dobri u jeziku poboljšali su se i imaju bolje ocjene, pa su više zainteresirani i više su motivirani (N 6).

Nastavnik mora imati kompetencije da prepozna učenikovu razinu jezika $i$ prilagodi se slabijim učenicima, ali nastavnik za to treba stvarno dobro znati jezik $i$ raditi kontinuirano na sebi. (N 8)

Nikada ne ocjenjujem znanje jezika, ne mogu jer nisam nastavnik stranoga jezika, bez obzira na kojoj su razini učenici. (N 6)

\subsection{Mjere za poboljšanje CLIL nastave}

Istraživanje je pokazalo da je nastavnicima potrebna stručna pedagoška, jezična i praktična pomoć za provedbu CLIL metodologije. Iako su nastavnici završili tečajeve CLIL metodologije u okviru projekta, nedostatak kontinuirane 
stručne podrške i nacionalnih smjernica za provedbu $C L I L$-a rezultira nesigurnošću nastavnika i nedostatkom standardizacije.

Nema nikoga tko nam može reći - moraš to raditi ovako, ili radiš to krivo. (N 8)

Radimo CLIL na svoj način, ne znamo je li dobro. (N 2)

Trebali bi imati nekoga... savjetnika za CLIL iz Agencije koji bi nam mogao pomoći, kao što postoje savjetnici za sve predmete u školama. (N 3)

Nastavnici su naveli kako tijekom i nakon provedbe $C L I L$-a nisu imali službenu potporu MZO-a, niti Agencije za odgoj i obrazovanje (AZOO). U Hrvatskoj također ne postoji pravilnik o CLIL-u, niti službene smjernice za provedbu CLIL metodologije. Nastavnici ističu kako bi trebalo osnovati nacionalni centar za izvođenje predmeta na stranome jeziku, te formalizirati CLIL u Hrvatskoj, možda uz pomoć AZOO-a. Osnivanje centralnog stručnog tijela za provedbu CLIL metodologije uvelike bi pomoglo nastavnicima. To bi tijelo moglo organizirati stručne edukacije i jezične tečajeve. Kako inicijalno obrazovanje nastavnika ne uključuje osposobljavanje za $C L I L$, a nastavnici svoje kompetencije razvijaju iskustvom (Ball, Kelly i Clegg 2015; Housen 2013), ulaganjem u profesionalno obrazovanje i usavršavanje nastavnika za poučavanje predmeta na stranome jeziku više bi se nastavnika osjećalo kompetentnima za provođenje same metodologije i poboljšala bi se kvaliteta nastave. Programi usavršavanja trebali bi se temeljiti na rezultatima istraživanja provedenim u školama u kojima se CLIL provodi, što bi izravno pomoglo razvijanju obrazovne i jezične politike.

Škole u kojima istraživanje pokazuje uspješno provođenje $C L I L$-a mogle bi biti primjerom ostalim školama i poslužiti kao vježbaonice za CLIL. Nadalje, nastavnici navode kako bi bilo iznimno korisno ispitati stavove svih nastavnika u svim školama koje provode $C L I L$, kao i usporediti stavove učenika o $C L I L$-u sa stavovima nastavnika. Svi su nastavnici istaknuli da bi im pripremu i provedbu CLIL nastave olakšala suradnja s CLIL stručnjakom koji bi imao ulogu trenera i supervizora, te osobe koja usmjerava i vodi CLIL nastavnike u njihovu profesionalnom CLIL razvoju.

Na pitanje što bi se u Hrvatskoj moglo učiniti kako bi se poboljšala CLIL praksa, nastavnici su jednoglasno odgovorili kako CLIL trebaju popularizirati i promovirati Ministarstvo znanosti i obrazovanja, te škole koje ga provode. 
CLIL bi na neki način trebao biti ukomponiran u kurikul, a Ministarstvo bi trebalo biti svjesno da CLIL postoji, ali mi smo privatna škola i prva koja je uvela CLIL. Krčimo put drugima! (N 1)

\section{ZAKLJUČCI I PREPORUKE}

Cilj je ovoga rada bio ispitati stavove nastavnika prema CLIL-u i utvrditi izazove s kojima se susreću pri provođenju CLIL nastave, te ponuditi odgovarajuće mjere za poboljšanje kvalitete učenja i poučavanja. Rezultati upućuju da nastavnici imaju pozitivan stav prema CLIL-u. Temeljni je izazov nastavnicima njihova nedostatna razina stranoga jezika. $\mathrm{S}$ obzirom na to da poteškoće u provedbi također stvara pronalazak i kreiranje materijala, povezivanje CLIL kurikula s nacionalnim kurikulom, te vrednovanje učenika trebalo bi organizirati radionice na kojima nastavnici mogu razmijeniti iskustva, a koje bi im i pomogle da razviju jezične kompetencije (Drljača-Margić i Vodopija-Krstanović 2018), ali i znanja i vještine za poučavanje (cf. Radić-Bojanić i Pop-Jovanov 2018). Razvidno je da je nastavnicima potrebna pomoć pri provođenju CLIL nastave i kontinuirano stručno usavršavanje, te da očekuju veću potporu i suradnju s nadležnim ustanovama $\mathrm{i}$ CLIL stručnjacima.

Nastavnici smatraju da se odnos prema CLIL nastavi i njoj primjerena potpora ne bi trebali razlikovati od istih usmjerenih na nastavu na materinskome jeziku. Iako CLIL nije široko rasprostranjen, ipak se provodi u javnim i privatnim srednjim školama, te bi valjalo službeno organizirati ciljanu stručnu podršku za nastavnike u CLIL-u, nadzor za CLIL nastavu, sustavnu jezičnu potporu nastavnicima, radionice za CLIL metodu i razrađen kurikul koji bi definirao i integrirao i jezične ishode na pojedinim predmetima. Neosporno je da je potrebno stručno usavršavanje nastavnika u području poučavanja sadržaja na stranome jeziku i poučavanja jezika putem sadržaja predmeta. Takva bi se podrška trebala nuditi unutar AZOO-a, a mogla bi se temeljiti na Europskom okviru za obrazovanje nastavnika za CLIL (vidi Mehisto, Marsh i Frigols 2008). Fakulteti koji se bave inicijalnim obrazovanjem nastavnika, pogotovo filozofski fakulteti koji nude dvopredmetne studije stranoga jezika u kombinaciji s drugim nejezičnim studijskim programom, trebali bi ponuditi predmet u okviru nastavničkoga modula koji bi osposobio studente za CLIL, te tako omogućiti zainteresiranim studentima da steknu praktične kompetencije u CLIL školama vježbaonicama. Također, stručni ispiti za nastavnike pripravnike u CLIL-u trebali bi se ostvarivati interdisciplinarno u nazočnosti dvaju nastavnika metodika (jezika i predmeta). 
Rezultati ovog istraživanja, te prijedlozi nastavnika mogu poslužiti za daljnje komparativne analize kao smjernica za škole koje planiraju uvesti CLIL u različitim obrazovnim kontekstima. Neosporno je da je potrebna veća suradnja svih škola koje provode CLIL u nacionalnom kontekstu, ali i povezivanje s europskim školama u kojima se provodi CLIL i koje imaju veće iskustvo s tim oblikom nastave, osobito s najbližim susjedima, primjerice Austrijom i Slovenijom. Usprkos svim prijedlozima, jasno je da ne postoji jedinstveni recept za $C L I L$, jer kvaliteta provedbe i poučavanja u $C L I L$-u uvelike ovisi o analizi obrazovnog konteksta, te procjeni potreba ljudskih i materijalnih resursa. Stoga su nužna daljnja istraživanja i veća educiranost nastavnika, sveučilišnih nastavnika metodika i svih sudionika obrazovnoga procesa kako bi svi bili upoznati s CLIL programom i brojnim čimbenicima koji doprinose ili umanjuju kvalitetnu provedbu $C L I L$ metodologije.

\section{LITERATURA}

Ball, P., Kelly. K., Clegg, J. (2015). Putting CLIL into Practice. Oxford: Oxford University Press.

Badertscher, H., Bieri, T. (2009). Wissenserwerb im Content and Language Integrated Learning, Empirische Befunde und Interpretationen. Bern: Haupt.

Basturkmen, H. (2018). Dealing with language issues during subject teaching in EMI: The perspectives of two accounting lecturers. TESOL Quarterly 52 (3): 692-700. DOI: 10.1002/tesq.460.

Bićanić, D. J., Opašić, G. M. (2019). Korektivna povratna informacija u poučavanju materinskoga jezika. Methodical Perspectives 10 (10): 13-31. DOI: $10.19090 / \mathrm{mv} .2019 .10 .13-31$.

Brevik, L. M., Moe, E. (2012). Effects of CLIL teaching on langauge outcomes, in Collabration in Language Testing and Assessment, ed. D. Tsagari, I. Csépes (Pieterlen: Peter Lang): 213-227.

Chen, Y-L. E., Kraklow, D. (2014). Taiwanese college students' motivation and engagement for English learning in the context of internationalisation at home: A comparison of students in EMI and non-EMI programs. Journal of Studies in International Education: 1-19. DOI: $10.1177 / 1028315314533607$.

Council recommendation of 22 May 2018 on Key Competences for LifeLong Learning. Pristupljeno 1. 2. 2020. URL: <https://eurlex.europa.eu/legalcontent/EN/TXT/PDF/?uri=CELEX:32018H0604\%280 $1 \% 29>$. 
Council recommendation of 22 May 2019 on a comprehensive approach to the teaching and learning of languages. Pristupljeno 1. 12. 2019. URL: $<$ https://eur-lex.europa.eu/legal-

content/EN/TXT/?uri=uriserv\%3AOJ.C_.2019.189.01.0015.01.ENG\&toc= OJ\%3AC\%3A2019\%3A189\%3ATOC>.

Council resolution of 31 March 1995 on improving and diversifying language learning and teaching within the education systems of the European Union. Pristupljeno 1. 10. 2010. URL: <https://eur-lex.europa.eu/legalcontent/EN/TXT/PDF/?uri=CELEX:31995Y0812(01)\&from=EN>.

Drljača Margić, B., Vodopija-Krstanović, I. (2017). English-medium Instruction: Glocal Insues Higher Education. Oxford/Bern/Berlin/Bruxelles/Frankfurt am Main/New York/Wein: Peter Lang. DOI: 10.3726/b10418.

Drljača Margić, B., Vodopija-Krstanović, I. (2018). Language development for English-mediuminstruction: Teachers' perceptions, reflections and learning. Journal of English for Academic Purposes 35: 31-41. DOI: 10.1016/j.jeap.2018.06.005.

Cenoz, J. (2015). Content-based instruction and content and language integrated learning: The same or different? Language. Culture and Curriculum 28 (1): 8-24. DOI: 10.1080/07908318.2014.1000922

Coyle, D. (1999). Theory and planning for effective classrooms: Supporting students in content and language integrated learning contexts, in Learning through a foreign language, ed. M. John (London: CILT): 46-62.

Coyle, D., Hood, P., Marsh, D. (2010). CLIL: Content and language integrated learning. United Kingdom: Cambridge University Press.

Dalton-Puffer, C. (2007). Discourse in content and language integrated learning (CLIL) classrooms. Amsterdam: John Benjamins.

Dalton-Puffer, C. (2008). Outcomes and processes in content and language integrated learning (CLIL): Current research from Europe, in Future Perspectives for English Language Teaching, eds. W. Delanoy, L. Volkmann (Heidelberg: Carl Winter): 139-157.

Dalton-Puffer, C. (2011). Content-and-language integrated learning: From practice to principles? Annual Review of Applied Linguistics 31: 182-204. DOI: 10.1017/S0267190511000092.

Denzin, N. K., Lincoln, Y. S. (1998). Strategies of Qualitative Inquiry. Thousand Oaks: Sage Publications. 
Eurydice (2006). Content and language integrated learning at school in Europe. Brussels: Eurydice European Unit. Pristupljeno 15. 7. 2019. URL: <http://eacea.ec.europa.eu/education/eurydice/all_publications_en.php>.

Eurydice (2017). Eurydice Brief: Key Data on Teaching Languages at School in Europe. $\quad$ Pristupljeno $31.2019 . \quad$. 2 URL: $<$ https://eacea.ec.europa.eu/national-policies/eurydice/content/eurydicebriefkey-data-teaching-languages-school-europe_en>.

Geiger-Jaillet, A., Wolff, D., Mehisto, P., Marsh, D. (2011). European Framework for CLIL Teacher Education. Graz: European Centre for Modern languages.

Gibbs, G. (2008). Analysing Qualitative Data. Thousand Oaks: Sage Publications.

Graddol, D. (2006). English Next. London: British Council. Pristupljeno 30. 8. 2010.

URL:

<https://www.teachingenglish.org.uk/sites/teacheng/files/pub_english_next .pdf $>$

Heine. L. (2008). Task-based cognition of bilingual learners in subject-specific cintexts, in Task-Based Language Learning and Teaching: Theoretical, Methodological and Pedagogical Perspectives, eds. J. Eckerth, S. Seiksmann (Frankfurt am Main, Berlin, Bern, Bruxelles, New York, Oxford, Wien: Peter Lang): 203-226.

Hendrikx, I., Van Goethem, K. (2020). Receptive knowledge of intensifying adjectival compounds: Belgian French-speaking CLIL and non-CLIL learners of Dutch and English. International Journal of Bilingual Education and Bilingualism: 1-25.

DOI: $10.1080 / 13670050.2020 .1720592$.

Housen, A. (2013). Processes and Outcomes in the European Schools Model of Multilingual Education. Bilingual Research Journal 26 (1): 45-64. DOI: 10.1080/15235882.2002.10668698.

Kampmark, N. V. (2019). EAL in vocational education: needs analysis and course syllabus design. Methodical Perspectives 10 (10): 113-137. DOI: 10.19090/mv.2019.10.113-137.

Jenkins, J. (2007). English as a Lingua Franca: Attitude and Identity. Oxford: Oxford University Press.

Kong, S. (2009). Content-based instruction: What can we learn from contenttrained teachers' and language-trained teachers' pedagogies? The Canadian Modern Language Review/La revue canadienne des langues vivantes 66 (2): 233-267. DOI: 10.3138/cmlr.66.2.233. 
Lasagabaster, D. (2008). Foreign language competence in content and language integrated courses. The Open Applied Linguistics Journal 1 (1): 31-42. DOI: $10.2174 / 1874913500801010030$.

Lasgabaster, D., Doiz, A. (2016). CLIL students' perceptions of their language learning process: delving into self-perceived improvement and instructional preferences. Language awareness 25 (1-2): 1-17. DOI: 10.1080/09658416.2015.1122019.

Lo, Y. Y. (2014). Collaboration between L2 and content subject teacher in CBI: Contrasting beliefs and attitudes. RELC Journal 45 (2): 181-196. DOI: $10.1177 / 0033688214535054$.

Lo, Y. Y. (2020). Professional Development of CLIL Teachers. Singapore: Springer.

Lyster, R., Mori, H. E. (2006). Interactional feedback and instructional counterbalance. Studies in Second Language Acquisition 28: 269-300. DOI: $10.1017 / \mathrm{S} 0272263106060128$.

Mariño, C. M. (2014). Towards implementing CLIL at CBS (Tunja, Colombia). Colombian Applied Linguistics Journal 16 (2): 151-160. DOI: 10.14483.

Marsh, H. W., Hau, K. T., Kong, C. T. (2002). Multilevel causal ordering of academic self-concept an achievement: Influence of language of instruction (English vs. Chinese) for Hong Kong students. American Educational Research Journal 39: 727-763. DOI: 10.3102/00028312039003727.

Marsh, D., Mehisto, P., Wolff, D., Frigols M. J. (2010). European Framework for CLIL Teacher Education. Graz: European Centre for Modern languages. Pristupljeno 1. 2. 2012.

URL: <https://www.unifg.it/sites/default/files/allegatiparagrafo/20-012014/european_framework_for_clil_teacher_education.pdf $>$.

McDougald, J. (2015). Teachers' attitudes, perceptions and experiences in CLIL: A look at content and language. Colombian Applied Linguistics Journal 17 (1): 25-41. DOI: 10.14483/udistrital.jour.calj.2015.1.a02.

McKay, S. L. (2018). English as an international language: What it is and what it means for pedagogy. RELC Journal 49(1): 9-23. DOI: $10.1177 / 0033688217738817$.

Mehisto, P., Marsh, D., Frigols, M. J. (2008). Uncovering CLIL: Content and language integrated learning in bilingual and multilingual education. Oxford, UK: Macmillan. 
Merino, J. A., Lasagabaster, D. (2018). The effect of content and language integrated learning programmes' intensity on English proficiency: A longitudinal study. International Journal of Applied Linguistics 28 (1): 1830. DOI: $10.1111 /$ ijal.12177.

Met, M. (1994). Teaching Content Through a Second language, in Educating Second Language Children: The Whole Child, the Whole Curriculum, the Whole Community, ed. F. Genesee (Cambridge University Press: New York): 159-182.

Nikula, T. (2017). CLIL: A European Approach to Bilingual Education, in Second and Foreign language Education, eds. N. Van Deusen-Scholl, S. May (Cham: Springer): 111-124.

Radić-Bojanić, B. B., Pop-Jovanov, D. M. (2018). Workshops in education: theoretical and practical issues. Methodical Perspectives 9 (9): 223-234. DOI: $10.19090 / \mathrm{mv} .2018 .9 .223-234$.

Ruiz de Zarobe, Y. (2008). CLIL and Foreign Language Learning: A Longitudinal Study in the Basque Country. International CLIL Research Journal 1 (1): $60-73$.

Serragiotto, G. (2007). Assessment and Evaluation in CLIL, in Diverse ContextsConverging Goals: CLIL in Europe, eds. D. Marsh, D. Wolff (Frankfurt: Peter Lang): 271-286.

Stoller, F., Fitzsimmons-Doolan, S. (2017). Content-Based Instruction, in Second and Foreign language Education, eds. N. Van Deusen-Scholl, S. May (Cham: Springer): 85-96.

Tsuneyoshi, R. (2005). Internationalization strategies in Japan. Journal of Research in International Education 4 (1): 65-68. DOI: 10.1177/1475240905050291.

Vázquez, V. P., Ellison, M. (2013). Examining teacher roles and competences in content and language integrated learning (CLIL). Linguarum Arena: Revista do Programa Doutoral em Didáctica de Línguas da Universidade do Porto 4: 65-78.

Vázquez, V. P., Méndez García, M. C. (2017). Analysing teachers' roles regarding cross-curricular coordination in Content and Language Integrated Learning (CLIL). Journal of English Studies 15: 235-260. DOI: 10.18172/jes.3227.

Vilkancienè, L., Rozgienè, I. (2017). CLIL teacher competences and attitudes. Sustainable Multilingualism 11 (1): 196-218. DOI: 10.1515/sm-20170019.

Vodopija-Krstanović, I., Brala Vukanović, M. (2012). EFL students' perspectives on English: the (widening) gap between ideals and practices. Revista 
Brasilera de Linguística Aplicada (Brazilian Journal of Applied Linguistics) 12 (2): 285-309. DOI: 10.1590/S1984-63982012000200004.

Vodopija-Krstanović, I., Marinac, M. (2019). English as an International Language and English Language Teaching: The Theory vs. Practise Divide. Iranian Journal of Language Teaching Research 7 (2): 19-38. Pristupljeno 10. 10. 2019. URL:< http://ijltr.urmia.ac.ir/article_120696.html>.

White Paper on Education and training - Teaching and Learning Towards the Learning Society 1995. Pristupljeno 31. 3. 2006. URL: $<$ https://op.europa.eu/en/publication-detail/-/publication/8722c9fb-71da435f-94b6-33aab67eb081/language-en/format-PDF/source-search>.

Irena V. Vodopija-Krstanović, Assoc. Prof.

University of Rijeka

Faculty of Humanities and Social Sciences, Departman of English

Dorina R. Badurina, M. A.

Secondary School Andrije Ljudevita Adamića, Rijeka

\section{CONTENT AND LANGUAGE INTEGRATED LEARNING (CLIL): BENEFITS, CHALLENGES AND MEASURES}

\section{Summary}

Content and language integrated learning (CLIL) is considered to be an innovative approach to fostering multilingualism in education in Europe (cf. Merino and Lasagabaster 2018). In order to accomplish this goal, CLIL teachers should have linguistic and methodological competences for subject teaching, assessment, materials development and classroom management in a foreign language. However, not many subject teachers have the necessary language skills, nor have they been trained in multilingual teaching (Vilkancienè and Rozgiene 2017). In fact, few teachers have gained formal qualifications in CLIL, and the majority learn how to teach CLIL while on the job (Ball et. al. 2015). Given that CLIL imposes increased demands on educators, this study aims to provide insights into teachers' attitudes towards CLIL, the challenges they face and the measures that should be taken to improve the quality and effectiveness of teaching. The case-study research consists of semistructured interviews with eight high school teachers involved in CLIL. The findings show that the common problems they face are related to: a) inadequate language proficiency, b) dual-focused form of instruction, c) selection, adaptation and design of course material, d) alignment of CLIL subjects with national guidelines, and e) assessment of student knowledge. What the teachers also complain about is a lack of support and guidance for CLIL education at the national level. Therefore, they would like to see formal CLIL teacher training, proper support for and supervision of teachers, clear directions in curriculum development, better inter-institutional collaboration, and effective communication and cooperation between the Ministry od Science and Education, Education and Teacher 
Training Agency, and CLIL schools. It will be argued that CLIL warrants greater attention and consideration from national institutions, higher education program developers, and secondary education policy makers.

Key words: CLIL, teachers, attitudes, challenges, measures, foreign languages, teaching.

Primljeno: 20. 4. 2020.

Prihvaćeno: 10. 8. 2020. 